\title{
Standing at the Waharoa
}

\author{
John O’Connor
}

PSYCHOTHERAPIST, AUCKLAND

\begin{abstract}
In this paper the author suggests that, when standing at the waharoa (gate) waiting for the karanga which calls us on to the marae, many of us, and particularly those whose ancestral histories originate in countries other than Aotearoa New Zealand, feel the apprehensive anticipation, if not disturbing terror, that comes with stepping into a cultural context so imbued with the painful colonial histories of this country. The paper explores how this history impacts upon us in cross-cultural encounters in Aotearoa New Zealand, and in particular in encounters between Māori and non-Māori, and the challenges and opportunities such encounters offer for the psychotherapeutic clinical encounter.
\end{abstract}

\section{Whakarāpopotonga}

I roto i tēnei pepa e hōmai pēnei ana te kaituhi, inā tū ana ki te waharoa ki te tatari i te karanga whakaeke, ko te maha o tātau,ā, pū tonu ki te hunga nō tāwāhi ngā tīpuna, e rongo ana i te mānukanuka, te mataku rānei i runga i te hou atu ki roto i tētahi horopaki ahurei kikī ana i ngā hìtori pēhitanga mamae o tēnei motu. Ko tā te pepa he tūhura i te awe o tēnei hìtori tau mai ki a tātau i roto i ngā whakawhitiwhitinga hui ahurei i roto o Aotearoa, pū tonu ki ngā hui tahitanga i waenga i te iwi Māori me iwi-kē, me ngā wero ngā pai puta ake i ēnei tūmomo huihuinga hai koha atu ki te mō ngā huinga whakaronga hinengaro.

Keywords: psychotherapy; shame; cross-cultural; marae; Māori

\section{Introduction}

When I was seven my mother took me to see the stage show Jesus Christ, Super Star. Judas was played by a white man and Jesus by a man whose skin was blacker than any I had ever seen before. I liked the show and said to Mum afterwards, "That was really good - but they should have had Jesus played by a white man and Judas played by a black man," to which my mum paused and then piercingly asked me, “... Why?” In that moment shame drenched me as I encountered not only the prejudice of my young mind - but the unknown racism of a country and a world about which I knew so little and yet from which I had taken in so much. In this paper I explore how Aotearoa New Zealand's colonial history, and the shame it engenders, impacts upon me as a person and a psychotherapist.

O'Connor, J. (2020). Standing at the waharoa. Ata: Journal of Psychotherapy Aotearoa New Zealand, 24(1), 67-78. https://doi.org/10.9791/ajpanz.2020.06 


\section{Shame}

In the 1990s, Elizabeth Carr (1999) posed the question, "Is shame the central affect of disorders of the self?" In turn I question, "What if shame is a central affect of a disordered and traumatised country, a country so often depicted as a tranquil escape, peaceful, and at ease with itself, Aotearoa New Zealand?" For New Zealand's colonial history has, I suggest, left a deep legacy of shame in the psyches of those like me, of British origin, whose ancestors initiated the colonial project in Aotearoa New Zealand, and I suggest this shame infuses cross-cultural relationships, particularly with indigenous Māori.

This shame and the paralysis it invites is potently encountered when I prepare to step onto a marae. Each time I stand at the waharoa (entrance gate) of a marae, waiting for the karanga (call) to step forward on to the marae and to engage across the marae atea (sacred space), to mihi (speak), and waiata (song in support of speech), I am frightened. I stand at the edge of my country's history, at the margins of my capacity to breathe. I stand on the shoulders of a history that includes the words of Henry Williams, one of my colonial ancestors and a man largely responsible for the translation of the Māori text of Te Tiriti o Waitangi, the Treaty of Waitangi (documents which outline an agreement between indigenous Māori and New Zealand's British colonists and which are central to New Zealand's history and contemporary constitutional arrangements). On the fifth of February 1840, Williams stood to address the Māori chiefs who had gathered to contemplate the proposed document. In encouraging them to sign he described the treaty as, "An act of love towards [Māori] on the part of the Queen" (Orange,1987, p. 45). Psychotherapy has also been conceptualised as an act of love. Of course, as difficult and complex an act as love always is, but love nevertheless. Yet in regard to the Treaty it seems abundantly clear that we have often failed to live up to the potential to which we might hope this act aspires. The love that Williams referred to was at best paternalistic, the offer of the coloniser to the native, and the shadow of this act was inherently hostile and violent (Salmond, 2017).

The profound disturbances of this history are stirred in every bicultural encounter as I meet the dissociated pain of my ancestors' immigration, and I meet the history of colonisation this immigration initiated, in which my British ancestors came to this whenua (land), stood across from the marae, encountered otherness, and profoundly dehumanised the indigenous that they encountered. Wakefield in the 18 oos observed "nothing can remind one more forcibly of a monkey as one who has seen a Maori" (cited in Best, 1925, p. 120). Fanon (1982) described the tragic consequences of the projective dynamics that inevitably infuse colonial history, in which the colonised dark other must find themselves in the white person's eyes, leading the dark other to by psychically "torn asunder" (Dalal, 2002, p. 97). The shame of this experience disintegrates the soul and psyche of indigenous people who are its recipients. Metge (1986) described whakamā and its post-colonial manifestation within some Māori as a loss of mana that leads to "... inward alienation from oneself” (Marsden, cited in Metge, 1986, p. 77; see also Woodard, 2008).

And I stand with my own disavowed Irish and English history. A history littered in my psyche with absences, gaps, dissociated pain and unremembered losses. A history that drove ancestors in my paternal line five generations back to leave the desperation of their Irish roots, in search of economic and psychological wellbeing that their Irish origins could no longer provide. And of an English lineage, more unremembered than remembered, which 
led my ancestors, whose money arose from the god of alcohol and the possession of land, to come to a new place, to extend their largess. Michael O'Loughlin (2012) and Garratt O'Connor (1995) explored the personal meaning and consequences of the Irish famine of $1845^{-1} \delta_{52}$, in which over a million people died. They described 150 years of Irish silence intended to avoid facing the enormity of this tragedy, and O'Loughlin quoted Christine Kinealy's note that those who died "remained nameless and unrecorded. Hard to know or to mourn" (2006, p. xvii). He also posed the question, "What if all of us of Irish descent are emotionally orphaned, fleeing an apparently unmourned past that leaves us with a gaping hole, cut off from the narrative strands that would allow us to stride confidently into the future?" (O’Loughlin, 2012, p. 235).

Most in New Zealand were originally immigrants. Indeed, Dowd (2009) suggested these unremembered pasts haunt the psyches of all immigrants, particularly in this part of the world, with profound implications for our engagement with the indigenous other. She wrote of the collective dissociated loss of our "background of meaningful containment" and noted, “...the 'dissociated self-state' of our collective psychic history ... haunts the Australian [and, I suggest, New Zealand] psychic landscape. The unintegratable shock, terror and shame of arriving unknowing and unrecognised into an unknown and unrecognisable place contributes into a specific aspect of cultural anxiety as it is experienced here" (p.110).

As I pause halfway towards the marae atea I remember my dead, as do we all. As Barlow and Wineti (1991) noted, "the [manuhiri] visitors are welcomed along with the spirits of those who have passed on,... In this ... a union takes place between the dead of the visitors and the dead of the particular marae they are attending, and with all who have died ...” (p.15). Thus, in the silent pause that occurs each time I step onto the marae with others, the unmourned ancestors of my Irish and English history are acknowledged as are the ancestors of the mana whenua with whom I am about to engage.

And as I stand at the marae waharoa, I stand about to enter a context in which indigenous wisdom about the nature of the psyche is at the centre, my psychotherapeutic and cultural capital on the margins. A reversal of my usual experience in Aotearoa New Zealand. Thus, I stand not only about to surrender to a cultural perspective about which I know so little, I also stand with the cultural, political and personal history of our country and of my countries of origin.

In my fear how do I not be completely consumed, subsumed, and overwhelmed by the shame and emotional intensity of such history. Is it even possible for the fear, shame, the guilt of this moment, not to propel every action with which I engage?

Indeed, the impulse to project my own disavowed trauma into and onto the indigenous other, to proffer my guilt and shame for the aggression my ancestors perpetrated, whilst denying my own painful ancestral history, risks enacting the very trauma I am attempting to undo. I suggest that psychotherapy in relation to the "racialised" other has often been infused by the politics of melancholy, in which the guilty shame which arises in those of European heritage is enacted in the clinical moment with the racialised other, in which there is an unconscious request for forgiveness, indeed a desire for maternal care from those whom we are attempting to assist.

The losses are profound. Yet most of us decline Akhtar's (1999) poignant invitation to embrace the painful task of ongoing mourning to which our immigrant histories gesture. 
Indeed to get even close to mourning this history we have to negotiate the shame of colonisation which for those of us of British origins, our migration enabled, and which profoundly disrupts our capacity to bear the grief of the losses we have all both suffered and, to varying degrees, attempted to disown, in our reactive denial, idealisation or submission to the feeling that something bad has happened so someone must be bad, either the monkeys which Māori were constructed as being during the colonial project, or the white British descendant whose cruelty is perceived as inarguable.

The power of this history has been revealed to me in many cross-cultural clinical moments. Perhaps the most terrifying for me was many years ago when I was facilitating a therapeutic group in a maximum-security prison. I remember entering that prison, to be greeted by a sea of brown faces, the majority Māori, the remainder almost exclusively Pacific peoples, with just one or two white faces in front of me. The cultural wounding of our country's history sat before me in stark horror. I did my best to offer input in helping the men "manage their anger", but who could not be angry in the face of such trauma. Halfway through the group, one man stood abruptly, angrily throwing the desk in front of him to the floor, and shouted at me, "You have an answer for everything, don't you ... you skinny white maggot." In that moment the painful histories of our personal and cultural context collided. I could only guess at the ways in which the relentless white man's voice, with the answer for everything, had subjugated his own voice, telling him who to be, what to be and how to be, whilst taking from him the ground of his being. In my voice, the voice of the liberal, caring, European man, resourced by the layers of privilege behind me, and then subsumed into impotent, silent guilt in response to the black man's aggression which inevitably I constructed as dangerous and violent, there emerged the avoidance of the grief, the impossibility of understanding what took place between us. Indeed, of course grief and the possibility of mourning, so eloquently evoked by Akhtar (1999), is a luxury only possible when one's basic survival is not threatened. A maximum-security prison is no place for grief. And perhaps neither is grief possible in a country gripped by generations of cultural trauma. Immediately another Māori man, the unnamed but clear leader of this group, a participant in it, stood and said, "John, we're gonna take a break." The prisoners left the room for about 10 minutes. When they returned, the man who had become so angry at me for the relentlessness of my voice and the whiteness of my skinny frame stood drenched in whakamā (shame), his eyes to the floor, and mumbled a frightened apology, saying he was sorry, and that this would not happen again. I could only imagine the pressure put on him by his peers in the group to mumble this apology, who did not want to lose the "prison privilege" of a therapeutic group. And for us all to avoid the unending grief that might underpin this exchange, the pain of our combined histories and the inability to begin to approach the vulnerability underpinning those histories.

How do we not be completely consumed, subsumed, by the shame of such history? Benjamin (2018) suggested that to get beyond the doer/done to dynamic we must co-create a symbolic third in which the multiplicity of self-experience can be heard. It is a possibility that is rarely enabled in New Zealand. I suggest that to do so we must negotiate the immense emotional challenge of encountering the others in ourselves, not only intra-psychically formed, but also unconsciously colour coded and formed within a socio-political and cultural force field of external tensions, fears and violence. To accept this emotional 
challenge, it is to avoid the temptations of manic restoration that Henri Rey (1994) described, in which we the guilty non-Māori seek absolution for the violent aggression of our ancestors, by manic restoration in the form of submission, guilt or idealisation, or the opposite, reactive denial or impotent bystander avoidance.

In inviting us to meet the grief of our histories it would be easy for you to understand me as inviting us all to submit to our shame, to attack ourselves for the badness of our histories, to decide that something bad has happened so it must be me, the descendant of the perpetrator of colonial horror, or in reactive denial to reverse the shame by blaming the aggrieved, the badness in the cultural other. In the fury of the moment with the man in the prison so many years ago I barely remember my response except that I fell into terrified and paralysed silence, unable to speak, so great was the fury and the projective hatred that flew between us. In my silence I disappeared my own aggression. I could so easily have counter-attacked, "Fuck you, you brown prick, I'm just trying to help, give me a break, I'm one of the good guys ... arsehole"; or more intellectually defensive, "Take responsibility for your own violence, it's yours alone, you need to face it"; or as was more likely back then, I might have submitted to my badness, "I'm sorry, you're right, I have no right to attempt to offer you anything, I'm your oppressor yet again, I will banish myself from your sight and psyche." Almost for certain all of these responses coursed through my internal world as I struggled to find my mind.

But I am suggesting the emotional challenge of engagement is much greater than these tempting escapes. Rey's description of what he referred to as "reparation proper" (1994, p. 222) involves reparation not merely of external reality, but of the inner object; in the crosscultural context this requires us to engage deeply with our own impulses to projectively hate, or reactively deny, avoid or idealise. To negotiate the shame of the persecutor, and the fear that my own aggression might be toxic, destructive and bad, as I attempt to move beyond the paranoid-schizoid position of attack and defence, and move towards the grief underpinning this, it is this which might lead to a reparation between cultures, rather than a submissive restoration which avoids real change. To find my mind, to be conscious of my own cultural histories littered as they are with violence and dissociated losses, and perhaps to offer to the man in my prison group, "I do not understand. I would like to understand, to whatever degree that is possible. But to do so we have to find a way to reach each other. Neither to kill each other off with our hate, nor submit to the idea that one of us is bad, but rather to find a place to begin to understand our shared and separate histories, including the almost unbearable disparities of privilege and power that exist between us, and the violence this reflects, and from there to find out what is possible. I do not have the answers to everything, or even anything. But we can grapple together for something new between us."

Or more concisely, as I have often said in response to a painful cross-cultural critique, something like, "You're right, I do not understand. But if you abandon ship right now the possibility for us learning together will permanently disappear. We are both going to have to stick around if we are to discover what understanding might be possible between us. I'm up for it ... if you are?" Such a response still requires creative aggression; the potency that facilitates my capacity to stay present, neither to retaliate, nor submit, nor avoid; an aggression not incapacitated by shame and guilt, but at the same time committed to engagement in the service of seeking empathic emotional and spiritual connection. The aggression and care of a repaired inner cultural object, not the manic reparative action of 
the damaged inner world, reacting to its apparent damaging effect.

Yet even as I offer the above, as I grapple to find a response which might be creative, I am troubled. Such a stance still enables me to maintain the position as the healing one, the "psychotherapist", responding to the pain of the "wounded other", a witness to the other, but with all the cultural capital of the psychotherapist who "knows". Is a more profound surrender required of me?

\section{Clinical Example}

Another one of my patients, whose skin colour is so much darker than mine, brought to me a dream. She reported: "I was me but with a penis. I had dark skin but the penis was white. It was really big, like ridiculously big. I was jerking it off, and this massive amount of sperm just coming out ... really weird. It wasn't scary, yet I woke up just as if I had woken from a scary dream." She reflected that the dream felt like her trying to get back control of something she had lost. The layers of potential meaning in this dream seemed multiple. Her attacks on me in the therapy left me feeling the subjugated other, castrating me; perhaps her dream reflected an attempt to regain potency in response to both personal, cultural, and gendered subjugation. I wondered what unknowable cultural resonances reverberated between us. What did I create in my mind in response to the darkness of her skin, of the disavowed history of countries in which dark skin is the receptacle of disavowed European self-hatred, and white skin promoted as an idealised other, and what responses are created in the racialised other in response to my fair complexion?

Many of my patients have revealed that in their cultural difference, as they experience their perceived minority status with me, they feel a mixture of the fear that I will perpetrate an attack on their racialised selves, as has so often happened in the past, mixed with the introjected shame of cross-cultural colonial and/or racialised contact, in which the dark other must see themselves in the white man's eyes. They feel the impulse on the one hand to aggressively assert their difference and attack me for my privileged otherness, whilst testing whether I can possibly glimpse an understanding of their difference, or on the other hand the temptation to defensively idealise my whiteness, to create me as the saviour, to rescue them from their dark badness. The white superego and the black id. Such dynamics can be powerfully disabling.

I suggest that Rey's (1994) repaired inner object, capable of both forgiveness and being forgiven, is crucial to the psyche's capacity for recognition of the harmed other. The deep emotional challenge of repairing the shame-filled culturally constructed inner object is, I suggest, a foundation upon which true recognition of the other might arise. Thus, in contrast to Dalal's (2013) interpersonal emphasis on an ethical conversation, I emphasise that I believe the cross-cultural task is therefore not merely an interpersonal or intergroup challenge, but also, and perhaps most essentially, a deeply intrapsychic emotional challenge.

\section{Intrapsychic Repair Alone Not Sufficient}

However, whilst Rey's (1994) exploration of intrapsychic repair is very helpful as a foundation from which to encounter the cross-cultural other, intrapsychic exploration is far 
from sufficient. True intercultural repair also requires contact, deep, interpersonal and group-to-group intercultural contact, surrender and redress. Indeed Jessica Benjamin (2018), in reflecting on the mixed experiences of participants who engaged with South Africa's Truth and Reconciliation Commission, and on group-to-group encounters between Israelis and Palestinians, noted that it was the encounters in which participants were affectively immersed in the other's subjective emotional experience who reported real movement in their relations with each other. This is much more than the intrapsychic exploration of the well-meaning bystander.

From her intersubjective perspective Benjamin (2018) suggested we need both the political process of redress of harm caused, and processes of meaningful recognition of both the harmer and the harmed. She described the moral third, an engaged witness to social injustice, and noted,

On the one side, political efforts aiming for restoration of rights or reparations to those who have been harmed (slavery, colonisation, persecution, genocide) need to be supported by acknowledgement that tangibly and incontrovertibly affirms that this wrongness happened. However, opposing this process is the intense fear ... of admitting the truth of harming because the loss of goodness is intolerable to the rigidly organised psyche. The fear of losing goodness expresses itself in a sense of being unfairly attacked, rather than being asked to take responsibility. The consequent denial of harming ... The attachment to identity becomes organised by the imaginary battle of "only one can live”. (p. 247)

Gerson's (2009) passionate exploration of humanity's response to the Holocaust offers possibility. In his potent evocation of the need for a witnessing third in the face of horrific cultural trauma he commented,

... whenever individuals and nations turn away from historical truths and its legacies of pain.... Our anguish is first for the re-injuries to those who have directly suffered, and then it is for the damage of our own experience that is caused by the denials.... [the] immeasurable harm to [our] own capacity to think about, feel, and to contain responsibly the murderous aggression and wanton indifference that haunt our humanity. (p. 1354)

His invitation to embody the stance of the witnessing third draws me forward. But I think we can and need to offer more than witnessing. We in New Zealand are asked to engage, to become intersubjectively and interculturally immersed, and availably present to the centre of indigenous experience: to feel the grief of the indigenous, and my own grief, to surrender but not submit, to be present to the other whom my colour-coded unconscious so quickly dehumanises, to feel the grief of all our combined violent migrant histories, to allow and enable the "shared labour of relational mourning" (Gerson, 2009, p. 1351) and the creative, often forceful, exploration of difference. I am more than a witness, I am participating, and I am engaged.

Gerson (2009) offered us a deeply moving, very challenging, excruciatingly distressing 
example of such witnessing. He described Helen Bamber, the founder of the medical foundation for victims of torture in London, who in 1945 entered the newly liberated concentration camp of Bergen-Belsen. Bamber reported, "people were in very difficult situations, sitting on the floor, they would hold onto you and dig their fingers into your flesh and they would rock and they would rock and we would rock together ... I remember saying to one person, who I didn't think would live very long, that I would hold her story and her story would be told" (p.1354).

This is the action of a deeply engaged other, not only a witness but a deeply engaged participant in the other's horror. Whilst the trauma we all face as we stand on the edge of the marae meeting the other across cultural and political difference may not be as viscerally visible to us as the description above, nevertheless I suggest the trauma is just as real. In the call for our active participation is just as equally a call to our humanity to provide a lifeline for both doer and done to from which new relational and cross-cultural understandings might emerge.

\section{A Collision of Cosmologies}

In her book Tears of Rangi: Experiments across worlds Anne Salmond (2017) skilfully articulates both Indigenous and European constructions of early encounters between Māori and nonMāori in Aotearoa New Zealand. For example, in exploring the death of the Mãori Chief Ruatara in 1815 , she notes,

Convinced that Ruatara's hau was being assailed by atua (powerful ancestors), perhaps those of the Europeans, the tohunga (priest) isolated the young chief from all but his closest relatives and tried to prevent the missionaries from visiting the tapu enclosure. The Europeans, on the other hand, understood Ruatara's affliction to be a "violent cold ... attended with inflammatory symptoms". Accordingly, they visited him, and tried to assist his recovery with gifts of food, drink and medicines. The scene was set for an ontological collision, with Ruatara's life in the balance. Competing cosmology swirled around his sick bed. Ideas of ora and life, mate and death, tapu and the Christian God, atua and Satan, hau and the immortal soul battled it out over his wracked, tormented body. (p. 58$)$

As the above example illustrates, in these earliest of cross-cultural encounters in Aotearoa New Zealand, cosmologies collided, and I would suggest, have collided ever since. Further, European constructions of these encounters have come to dominate the majority of written historical texts exploring such events and their meanings, with the consequence that these "histories" have powerfully influenced the subsequent theory and practice of much that influences the practices of health and healing in the contemporary Aotearoa New Zealand context, including and specifically, psychotherapy. As Woodard (2014) noted, with the passing of the Tohunga Suppression Act 1907 came the driving "underground" of indigenous knowledge and perspectives regarding the interconnected nature of, and practice in relation to, psyche; the "Māori patient" was inevitably positioned as marginalised resisters of this Eurocentric dominance, a theme which runs throughout the life of 
psychotherapy in Aotearoa New Zealand subsequently. Indeed Mika and Stewart (2016) suggested that the West has a "primal need ... to control how and when Māori will manifest as this or that, including as a wanting entity... [that the West] has... canonically guessed Māori in advance as either needing or wanting something in particular, or generally being needing and wanting” (p.305). In this, the colonial gaze on the indigenous other is evident even before contact, constructed as the gaze of the Western Christian colonial power "gazing" on the heathen indigenous other in need of salvation. In my responses to the man in the prison, do I perpetuate this gaze, unable to bear the terror, and the grief, that might come with surrendering to all that I do not know?

In recent decades, within many contexts in Aotearoa New Zealand, and certainly within the psychotherapy context, indigenous Māori have challenged us to recognise indigenous wisdom. This challenge invites all who are engaged in the complex art of healing the psyche to engage in a deeply destabilising, and potentially rich opportunity. Whilst it is tempting to be frightened, and to resort to responses of submission, idealisation, rejection, and bystander denial, the opportunity of the indigenous challenge is to deeply and meaningfully engage with the indigenous wisdom, with Te Ao Māori perspectives on the nature of psyche and of healing. In this we are engaging in a unique and vital experience of psychotherapy, one which many overseas psychotherapy guests have commented on with profound appreciation. Such a stance invites me to do more than meet across the cultural difference; it invites me to surrender to that difference, to leave behind the cultural capital of my psychotherapeutic certainty, and to surrender to the terror of encountering the other from within their cultural world, about which I know so little.

Marae experiences, I suggest, offer the opportunity for such profound processes of recognition and surrender. The indigenous voice in Aotearoa New Zealand is strong and growing stronger. In my experience pōwhiri (ceremony of welcome) is not only a gesture of love and extraordinarily generous hospitality given the violent trauma of our histories; it is also a creative act of aggression, inviting me to consider my intentions. The hongi (pressing of noses) which follows the whaikōrero (speeches) enables the sharing of the breath of life, a gift from the gods to us all, the embrace of the ancestors which come with us and the grief of their presence and absence, the coming together of two groups and the possibility that something creative might emerge. Most of the time in Aotearoa New Zealand I am at the centre. Resourced but also shackled. Standing at the gate about to enter the marae, I glimpse life at the margins. Frightened, yes: but also freer, more creative. As I stand about to enter this place at the centre for the tangata whenua (people) of New Zealand, I am enriched by the possibility of two centres meeting, two taboos touching. Indeed, now when I stand to speak on the marae, I still feel nervous, my heart still beats quicker as I struggle to find my Te Reo Māori words, but shame is no longer so quick to descend, even when fiercely critiqued. For in standing, in showing up, I am offering a counterpoint to my place of dominance at the cultural centre. Beyond witnessing, I am embracing the invitation to surrender to the experience of the one who does not know, and the possibility of a relational and crosscultural engagement in which I am the receptive learner. Essential to this process for me is an inner object which no longer succumbs to impotent guilt; that can forgive and be forgiven, see and be seen, that can allow aggressive states to exist within me as I encounter aggressive states in the cultural other. To allow our differences to be visible, sometimes 
forcefully, with confidence in the possibility of transformation that true contact might allow, without turning on myself or the indigenous other.

Benjamin (2018) helpfully noted that when the kind of acknowledgement and recognition that sometimes occurs in marae encounters is made possible, the humanity of both the harmed and the harmer is restored, and recognition of our humanity and attachment to each other as part of the greater whole is enabled.

As I meet the cultural other in my room, there is so much I do not and cannot understand. There is so much new to potentially be revealed. If I can wait without demand, willing to speak the truth of my emotional experience as I meet the other, might this lead us to something more like transformation? It seems to me that if psychoanalysis is to embrace negative capability in relation to cross-cultural contact, this inherently means not imposing our meta-psychological theories on the other, not being captured by what Snell (2013) described as the "colonising gaze" (p. 33) of psychoanalysis, not holding to our notions of truth about the psyche, but rather being willing to embrace notions of truth about the psyche perhaps profoundly different to our own, whilst still holding on to our own minds. Exploring notions such as that of wairua (spirit, soul, essence) resonate with Jung's transcendent function and notion of the transpersonal Self; manaakitanga (hospitality, compassion, generosity) so evocative of Winnicott's (1965) primary maternal preoccupation; kaitiakitanga (guardianship), evocative of Bion's (1962) container; and ūkaipō, the feeding at the breast in the middle of the night, suggestive of the clinical experience of infantile distress and disturbance we so often encounter as we attempt to offer Bion's "contained" "good food". This is the possibility of two taboos touching, of a deep emotional engagement, of, as Symington suggested, "a meeting of souls" (2007, p. 58 ).

Traditionally during pōwhiri challenges are uttered, in part to ensure that the manuhiri (visitors) come in peace. As I stand at the waharoa, the karanga (call) from the kaikaranga (caller) acknowledges the dead descendants which come with us, both tangata whenua and manuhiri, the whai kōrero speeches pay respect to all that holds us, the divine, the land, the dead and the living, the earth and sky, mountains and rivers, the natural world that enables our spiritual and physical presence on the land. The hongi which follows enables the sharing of the breath of life, the embrace of the ancestors which come with us and the grief of their presence and absence, the coming together of two groups as one and the possibility that something creative might emerge between us. For me marae encounters are an invitation to embody Gerson's (2009) witnessing, and intersubjectively immersed, participating third: they evoke many memories of the marae encounter in which the possibility of our shared and separate griefs might be felt together, witnessed one with the other, with the hope that mourning might allow the emergence of something new between us. The task is demanding, but I have never engaged in any relationship that was even remotely satisfying, including the relationship I have with myself, without the depths of such a struggle.

\footnotetext{
Kia whakatōmuri te haere whakamua

My past is my present is my future

I walk backwards into the future

with my eyes fixed on my past
} 


\section{JOHN O'CONNOR}

\section{References}

Akhtar, S. (1999). Immigration and identity: Turmoil, treatment and transformation. Northvale, NJ: Aronson.

Barlow, C., \& Wineti, E. (1991).Tikanga whakaaro: Key concepts in Māori culture. Auckland, New Zealand: Oxford University Press.

Benjamin, J. (2018). Beyond doer and done to: Recognition theory, intersubjectivity and the third. London, England: Routledge.

Best, E. (1925). Games and pastimes of the Maori. Wellington, New Zealand: The Board of Maori Ethnological Research for the Dominion Museum.

Bion, W. R. (1962). Learning from experience. London, England: Karnac.

Carr, E. (Ed). (1999). Is shame the central affect of disorders of the self? Psychoanalytic Inquiry, 19(3).

Dalal, F. (2002). Race, colour and the processes of racialization. New York, NY: Routledge.

Dalal, F. (2013). The struggle to live and let live: The psychology, ethics and politics of tolerance, or, why discrimination is preferable to tolerance. Ata: Journal of Psychotherapy Aotearoa New Zealand, 17(2), 159-172.

Dowd, A. (2009) Backgrounds of beauty: Explorations in the subtle geography of identity and the interrelationships between psyche and place. Australian Journal of Psychotherapy, 2\&(1\&2), 96-113.

Fanon, F. (1982). Black skin, white masks. New York, NY: Grove Press.

Gerson, S. (2009). When the third is dead: Memory, mourning and witnessing in the aftermath of the Holocaust. International Journal of Psychoanalysis, 90(6), 1341-1357.

Kinealy, C. (2006). This great calamity: The Irish famine 1845-53. Dublin, Ireland: Gill and Macmillan.

Metge, J. (1986). In and out of touch: Whakamaa in cross cultural context. Wellington, New Zealand: Victoria University Press.

Mika, C., \& Stewart, G.(2016). Māori in the kingdom of the gaze: Subjects or critics. Educational Philosophy and Theory, 48(3), 300-312.

O'Connor, G. (1995). Recognising and healing malignant shame. Retrieved from http://v1.zonezero. com/magazine/essays/distant/zreco2.html

O'Loughlin, M. (2012). Trauma trails from Ireland's great hunger: A psychoanalytic inquiry. In B. Willock, R. Curtis, \& L. Bohm (Eds.), Loneliness and longing: Psychoanalytic reflections. New York, NY: Routledge.

Orange, C. (1987). The Treaty of Waitangi. Wellington, New Zealand: Allen \& Unwin New Zealand.

Rey, H. (1994). Universals of psychoanalysis in the treatment of psychotic and borderline states: Factors of space-time and language. London, England: Free Association Books.

Salmond, A. (2017). Tears of Rangi: Experiments across worlds. Auckland, New Zealand: Auckland University Press.

Snell, R. (2013). Uncertainties, mysteries, doubts: Romanticism and the analytic attitude. London, England: Routledge.

Symington, N. (2007). Becoming a person through psychoanalysis. London, England: Karnac.

Woodard, W. (2008). Entering the void. Unpublished Master's dissertation, Auckland University of Technology, Auckland, New Zealand.

Woodard, W. (2014). Politics, psychotherapy, and the 1907 Tohunga Suppression Act. Psychotherapy and Politics International, 12(1), 39-48.

Winnicott, D.W.(1965). The maturational processes and the facilitating environment: Studies in the theory of emotional development. London, England: The Hogarth Press and the Institute of Psycho-Analysis. 


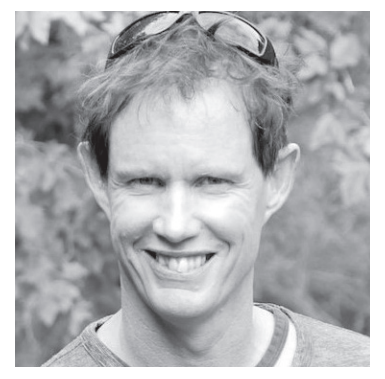

John O'Connor has worked as a counsellor and psychotherapist for over 30 years, and has a wide range of clinical experience, particularly in working with clients with severe trauma histories, in providing group psychotherapy, and in working cross-culturally. $\mathrm{He}$ is a former Director of Youthline Counselling Service (Auckland) and the Human Development and Training Institute. He also formerly worked at Segar House (which is part of ADHB Mental Health Services) and was a founding member of the therapeutic team at Segar which developed a residential treatment service (currently operating as a day programme) for clients with personality disorder diagnoses. He worked as a lecturer at the Auckland University of Technology within the Psychotherapy Discipline from 1999 until 2019 and was formerly Programme Leader of the Master of Psychotherapy (adult programme) at AUT. He is co-editor of Ata: Journal of Psychotherapy Aotearoa New Zealand. John conducts a private practice in Mangere Bridge. John is currently a candidate in training as a Jungian Analyst with the Australia New Zealand Society of Jungian Analysts and is undertaking his PhD exploring the discourses underpinning bicultural clinical encounters in Aotearoa New Zealand. Contact details: johnnygj@xtra.co.nz. Phone 021-899-261. 